\title{
Sage-Grouse Nesting, Brood and Winter Habitat Characteristics in Montana
}

\author{
Jennifer Woodward \\ Department of Animal and Range Sciences \\ PO Box 172900, Bozeman, MT 59717-2900, United States
}

Tel: 1-406-323-2103 ext. 108 E-mail: jennifer.woodward@mt.usda.gov

Jenny Sika

Montana Fish, Wildlife and Parks, Region 3

930 Custer Ave, Helena, MT 59620, United States

Tel: 1-406-495-3268Ｅmail: jsika@mt.gov

\author{
Carl Wambolt \\ Department of Animal and Range Sciences
}

PO Box 172900, Bozeman, MT 59717-2900, United States

Tel: 1-406-994-5580 E-mail: cwambolt@montana.edu

Jay Newell

Montana Fish, Wildlife and Parks, Region 5

$14252^{\text {nd }}$ Street West, Roundup, MT 59072, United States

Tel: 1-406-323-3170 E-mail: jaynewell@mt.gov

\section{Sean Schroff}

Department of Animal and Range Sciences

PO Box 172900, Bozeman, MT 59717-2900, United States

Tel: 1-405-994-5558Ｅ-mail: sean.schroff@ hotmail.com 
Bok Sowell (Corresponding author)

Department of Animal and Range Sciences

PO Box 172900, Bozeman, MT 59717-2900, United States

Tel: 1-405-994-5558Ｅ-mail: bok@montana.edu

Received: January 6, 2016 Accepted: January 26, 2016

doi:10.5296/emsd.v5i1.9048ＵRL: http://dx.doi.org/10.5296/emsd.v5i1.9048

\begin{abstract}
Greater sage-grouse (Centrocercus urophasianus) habitat characteristics were studied in central Montana primarily on Wyoming big sagebrush (Artemisia tridentata Nutt. ssp. wyomingensis Beetle \& Young) dominated rangeland. The primary objective was to compare shrub and herbaceous parameters within (use, random or non-use) and between seasonal habitats (nest, brood, winter). Two study sites (Musselshell and Golden Valley counties), and 2 years (2004 and 2005) were compared. Nest, brood, and random sites were compared for herbaceous cover, and grass height $(n=648)$. Nest, brood, random, winter use and winter non-use sites were evaluated for shrub cover, density, and height. All differences were considered significant at $\mathrm{P} \leq 0.05$. Sage-grouse nested in areas with greater total shrub cover and height, and taller live and residual grass than was randomly available. No differences were found between brood and paired random sites for any of the herbaceous or shrub parameters measured. Shrub cover and density were greater at winter use sites than non-use sites. Winter use sites had less shrub cover than nest sites. The nest and brood habitat had similar shrub cover, density, and height on the study area. Sage-grouse habitats should be managed to include sagebrush, forbs, and grass. Herbaceous vegetation was more important during nesting and brood rearing than during the winter. Therefore, some portions of sage-grouse habitat may benefit from management for greater herbaceous cover, but not at the expense of removing sagebrush. Sagebrush cover from 10 to 15 percent was the most consistent component of sage-grouse habitat.
\end{abstract}

Keywords: Wyoming big sagebrush, shrub cover, herbaceous cover, grass height

\title{
1. Introduction
}

It is estimated that the overall distribution of sage-grouse (Centrocercus spp.) has decreased by 50 percent since European settlement (Braun 1998). The historical distribution of greater sage-grouse (C. urophasianus) included 12 states and 3 Canadian provinces; currently sage-grouse have been extirpated from British Columbia and Nebraska (Schroeder et al., 2006).

Sage-grouse decline is most often attributed to a loss of habitat. Sage-grouse are sagebrush obligates, dependant on sagebrush for food, thermal cover, and hiding cover (Patterson, 1952, 
Wallestad, 1975). Montana currently supports 11 million ha of sage-grouse habitat; although it is estimated 50 percent of the original habitat has been lost (Montana Sage-grouse Work Group, 2002).

Sage-grouse habitat is quite variable due to variations in weather (especially snow depth), sagebrush taxa present, habitat types and patterns available, and topography of habitat (Eng and Schladweiler, 1972; Wallestad, 1975; Remington and Braun, 1985; Connelly, Schroeder, Sands and Braun, 2000). Few studies have had the opportunity to concurrently investigate nesting, brood rearing and winter habitats required by sage-grouse. Further information on sage-grouse in Montana would assist land managers in making decisions for sage-grouse.

Sage-grouse (Centrocercus urophasianus) hens (i.e. females) select areas with greater cover and heights of grasses and sagebrush (Artemisia spp.) for nesting sites (Connelly, Schroeder, Sands and Braun, 2000; Hagen, Connelly and Schroeder, 2007) Selection for areas of greater cover and herbaceous heights for nest sites can be higher in xeric sagebrush habitats types (e.g. Wyoming big sagebrush sites receiving annually $<25 \mathrm{~cm}$ of precipitation; Kirol, Beck, Dinkins and Conover, 2012; Boyd, Beck and Tanaka, et al., 2014).

Early brood-rearing habitat is generally defined by greater canopy cover of sagebrush, with greater abundances of forb and insects (Connelly, Schroeder, Sands and Braun, 2000; Aldridge and Brigham, 2002; Kirol, Beck, Dinkins and Conover, 2012). Late brood-rearing habitat is generally defined by more mesic sites that contain forbs and insects (Holloran, 1999; Connelly, Schroeder, Sands and Braun, 2000; Holloran and Anderson, 2005; Connelly, Rinkes and Braun, 2011; Kirol, Beck, Dinkins and Conover, 2012). Also, sage-grouse broods have been shown to avoid areas with higher densities of predators (Dinkins, Conover, Kirol and Beck, 2012; Dinkin, Conover, Kirol, Beck and Frey, 2014; Mabray and Conover, 2015).

In winter, sage-grouse feed almost exclusively on sagebrush (e.g. >99\%; Artemisia spp., Thacker, Gardner, Messmer, Guttery and Dahlgren, 2012). Sage-grouse winter habitat consists of areas dominated by sagebrush $(>75 \%)$ and avoid areas with other cover types (Doherty, Naugle, Walker, and Graham, 2008). Sage-grouse will select sites that have taller sagebrush ( $\geq 1 \mathrm{~m})$, especially in areas of greater snow depth (Dzialak et al., 2013).

The objective of our research was to compare shrub and herbaceous parameters within (use, random or non-use) and between seasonal habitats (nest, brood, winter) and 2 years (2004 and 2005).

\section{Methods}

\subsection{Study Area Description}

This study was conducted in central Montana with one location in Musselshell County and another in Golden Valley County, $25 \mathrm{~km}$ north and $32 \mathrm{~km}$ west of Roundup. The majority of the study area is privately owned (75 percent), with some land managed by the Bureau of Land Management (16 percent), and the remaining by the state ( 5 percent). Eighty-nine percent of the study area is used for range, beef and sheep production. The weather station in Roundup receives a mean annual precipitation of $32 \mathrm{~cm}$ (Western Regional Climate Center, 
2005). During the growing season (April to September) the area receives 75 percent of the annual mean average precipitation. The study area is made up of shale lowlands separated by sandstone ridges containing several undrained basins (USDA, 2003). The study sites consisted of the Wyoming big sagebrush (Artemisia tridentata Nutt ssp. wyomingensis Beetle \& Young) habitat type, greasewood (Sarcobatus vermicultatus (Hook.)Torr.) bottoms, native and introduced grasslands, and agricultural lands. This study was conducted in conjunction with Sika (2006) whose study focused on breeding ecology, survival rates and mortality causes of sage-grouse on the same study area.

\subsection{Collection of Bird Locations}

Over a 3 year period (2003 to 2005) sage-grouse were captured on or near leks during breeding season and fitted with a radio transmitter. A receiver was used to precisely locate sage-grouse and a geographic position system (GPS) was used to record exact location of tracks, fresh sage-grouse droppings, or nest location. Use sites were relocated with GPS in order to conduct habitat measurements. Winter sites were measured within 3 months from the time the birds were located. Nest and brood sites were measured within 7 days after bird location was collected via GPS.

\section{Measurements}

\subsection{Nesting Habitat}

Sagebrush canopy cover, density, and height, forb, grass, and herbaceous cover, and live and residual grass height were measured at each nest site. The height and average diameter of the shrub the hen nested under was determined. Nest shrub productivity was calculated by measuring the nest shrub's major axis, followed by a perpendicular minor axis, and $2-45^{\circ}$ crown width measurements, and is reported in grams of available winter forage (Wambolt, Creamer, and Rossi, 1994). All measurements were conducted on 2 perpendicular $30 \mathrm{~m} \mathrm{~N}-\mathrm{S}$ and $\mathrm{E}-\mathrm{W}$ transects, with the nest located at the center (15 m point) of each line.

Line intercept sampling was used to estimate shrub canopy cover, and height along transects (Canfield, 1941; Connelly, Reese and Schroeder, 2003). Gaps in shrubs $>3 \mathrm{~cm}(0.1 \mathrm{ft})$ were excluded. Shrub height was measured every $2 \mathrm{~m}$ on the nearest shrub with an average crown $>15 \mathrm{~cm}$ in diameter $(\mathrm{n}=15 /$ transect $)$. Belt transects were used to estimate shrub density (Connelly, Reese and Schroeder, 2003). All shrubs $>15 \mathrm{~cm}$ in diameter and rooted within $1 \mathrm{~m}$ of either side of the 3 to $30 \mathrm{~m}$ transect lines were recorded. Total herbaceous forb and grass cover were measured using $20 \times 50 \mathrm{~cm}$ quadrats (Daubenmire, 1959). A total of 20 quadrats were measured along each of the two transects. Vegetative droop height of living grass and residual grass was also recorded at each quadrat.

Random sites were paired with nest sites within the same habitat to test if hens were randomly selecting shrub or herbaceous characteristics for nesting. Shrub and herbaceous measurements were completed using the same methods as nest sites. Random sites were measured on the same or next day as their paired nest sites. At each nest site a random compass direction and distance (between $30 \mathrm{~m}$ and $1000 \mathrm{~m}$ ) were chosen using random number tables. The tallest sagebrush, nearest the end of the random distance was selected as 
the random nest shrub. If the habitat encountered at the random site was not sagebrush, such as an agricultural field, the closest sagebrush stand in the same direction was selected.

\subsection{Brood Rearing Habitat}

Hens with broods were tracked throughout the brood-rearing season. Shrub and herbaceous parameters at brood sites were measured using the same methods as nest sites. Paired random locations were selected in the same way as nest sites. Brood locations were located and measured at 1 and 4 weeks after hatch.

\subsection{Winter Habitat}

Winter habitat measurements were collected along 3 to $30 \mathrm{~m}$ transects. The sampling layout differed from nest and brood sites because typically during the winter birds are in flocks that are spread out across the landscape. The first transect was centered over droppings found at the GPS location of the use site. The second and third transects were $30 \mathrm{~m}$ to each side and parallel to the first transect. Shrub measurements including cover, density and height were completed precisely the same as for nest sites. Residual grass height (including inflorescence) and cover were measured at 2005 to 2006 winter use and non-use sites.

Sage-grouse winter non-use sites were established during the summer of 2005 and the winter of 2005 to 2006. Random points were placed on ArcGIS $9^{\circledR}$ within areas that were not known to be used heavily during winter. Random points were only placed in soil types that sage-grouse had used during our study. No random points were placed within $300 \mathrm{~m}$ of the actual winter bird location.

A GPS unit was used to locate sampling sites. An area of $1200 \mathrm{~m}^{2}$ was delineated around each GPS location for sampling. This area was searched thoroughly for droppings; if droppings were found the site was dropped from our analysis. Droppings were persistent for at least 6 months. At locations with no indication of use, $330 \mathrm{~m}$ transects, duplicating those in use sites were sampled. Sites with $<2$ percent sagebrush were discarded and not sampled as non-use sites.

\section{Analyses}

An analysis of variance (ANOVA) was conducted using the GLM version of SAS ${ }^{\circledR} 9.0$ to determine if sage-grouse habitat differed by season (nest, brood, random, winter, or winter non-use), or year (2004 and 2005). Nest, brood, and random sites were compared for total herbaceous, grass, and forb cover, and live and residual grass height. Nest and paired random sites were evaluated for nest shrub height, nest shrub productivity and crown diameter of nest shrub. Nest, brood, random, winter use and winter non-use sites were compared for total shrub canopy cover, total shrub density, and shrub height. The experimental unit was each bird location, or one sampled site, all transects from each site were averaged together. Effects in the model were compared with least squares means. Because data were unbalanced a Tukey-Kramer test was used to separate least squares means (Kramer, 1959). The linear model included all main effects (season, year, county) and all possible interactions. When interaction terms were not significant reduced models were fitted to the data. Least squares 
means are presented where no interactions were determined. Least squares means for the interactive terms are reported when interactions were significant. Residual grass height and cover from the 2005 to 2006 winter were analyzed with either 2-independent sample t-tests or Wilcoxon-Mann-Whitney tests depending on normality. These data could not be added to the ANOVA because of differences in sampling methodology. All differences were considered significant at $P \leq 0.05$.

Vegetative parameters were analyzed for 648 sites measured in 2004 and 2005. Sites with 0 percent shrub cover were omitted from the analyses. Included in the analysis were 22 sites where greasewood contributed $>50$ percent of total canopy cover, and 4 sites where silver sage contributed $>50$ percent total canopy cover. The remaining 626 sites (97 percent) sampled had $>50$ percent shrub cover of Wyoming big sagebrush. Wyoming big sagebrush, silver sagebrush, and greasewood sites were analyzed together as one shrub cover type in the ANOVA. Over 90 percent of shrub cover was from Wyoming big sagebrush.

\section{Results and Discussion}

\subsection{Nesting Habitat}

The importance of herbaceous and shrub cover for nest concealment has been demonstrated in previous studies (Connelly, Schroeder, Sands and Braun, 2000; Sveum, Edge, and Crawford, 1998). Sage-grouse nested in areas with greater total shrub cover (15 percent vs. 13 percent; $P<0.03)$ and height $(28 \mathrm{~cm}$ vs. $26 \mathrm{~cm} ; P<0.05)$, and taller live $(12 \mathrm{~cm}$ vs. $11 \mathrm{~cm})$ and residual grass $(9 \mathrm{~cm}$ vs. $8 \mathrm{~cm}$ ) than was randomly available in our study. When total shrub cover, residual grass height, or residual grass cover increased by 10 percent, the probability of a nest increased by 31.3 percent (Holloran et. al., 2005). The shrub under which the hen nested was taller $(50 \mathrm{~cm}$ vs. $44 \mathrm{~cm} ; P<0.001)$ and had greater productivity (61 g vs. $51 \mathrm{~g} ; P<0.001)$ than random shrubs in both years.

Due to increased precipitation in 2005, total herbaceous (18 percent vs. 13 percent), grass (15 percent vs. 12 percent), and forb cover ( 7 percent vs. 3 percent), and live grass height $(13 \mathrm{~cm}$ vs. $10 \mathrm{~cm})$ were greater $(P<0.001)$ in 2005 than 2004 . Average crown diameter was greater at nest sites than random sites in 2004 but similar in 2005 (figure 1). Sika (2006) found weak support for increased nest success in 2005 on the same study area. Coggins (1998) found nest success for sage-grouse increased in years with greater residual tall grass cover. Hausliner (2003) considered grass height to be a limiting factor for nest success during drought years. Herbaceous cover associated with nest sites may have provided scent, visual, and physical barriers to predators (DeLong, Crawford and DeLong Jr., 1995).

There was a greater number of re-nests (ie. $2^{\text {nd }}$ and $3^{\text {rd }}$ nest attempts) in 2005 than 2004. Re-nests were more successful (56 percent) than first nests (32 percent) (Sika, 2006). This was likely because of the increase in herbaceous cover. Although there was a higher proportion of successful nests in 2004, there was greater hen success in 2005 (success in raising a brood out of all of the females beginning the study) (Sika, 2006). Moynahan (2004) found that nesting probability increased when range condition was improved. 


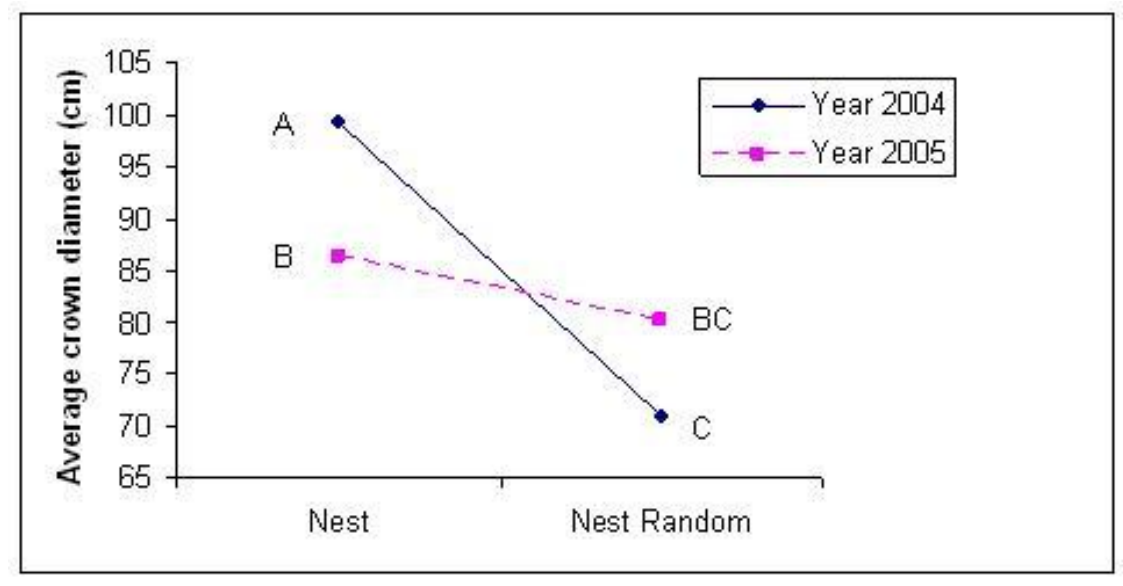

Figure 1. Interaction between year and seasonal habitat for average crown diameter of the nest shrub for nest and paired random sites in 2004 and 2005 in Golden Valley and Musselshell counties. Means differ $(P \leq 0.05)$ between sites when followed by a different letter.

\subsection{Brood Rearing Habitat}

No differences were found between brood and paired random sites for any of the herbaceous or shrub parameters measured on our study. Klebenow (1969) did not find a statistical difference between brood and random sites in Idaho. A meta-analysis of 7 sage-grouse studies throughout the west found areas used by broods $<6$ weeks of age had greater forb and grass cover, taller grass, and less sagebrush cover than random sites (Hagen, Connelly and Schroeder, 2007).

Sage-grouse broods may be selecting brood-rearing habitats based on predator avoidance more so than herbaceous and shrub components. Sage-grouse broods have been shown to avoid areas of high density of small and medium-sized avian predators (Dinkins et al. 2012, 2014; Mabray and Conover, 2015). This is a possible explanation for why we found no differences between brood and paired random sites for any of the herbaceous or shrub parameters measured in our study.

There was greater shrub height ( $29 \mathrm{~cm}$ vs. $25 \mathrm{~cm}$ ), total herbaceous cover (19 percent vs. 16 percent), forb cover (15 percent vs. 13 percent), and live grass height $(17 \mathrm{~cm} \mathrm{vs.} 11 \mathrm{~cm})$ in 2005 than $2004(P<0.001)$. Shrub density $\left(1.5 / \mathrm{m}^{2}\right.$ vs. $\left.1.1 / \mathrm{m}^{2}\right)$ and residual grass height $(9 \mathrm{~cm}$ vs. $5 \mathrm{~cm}$ ) were greater in 2004 than 2005, indicating broods used different areas in years with different precipitation. Broods in southern Oregon and southern Idaho used areas with the greatest forb cover (Klebenow, 1969; Drut, Crawford and Gregg, 1994). Forbs, insects, and sagebrush are the primary food sources for young chicks (Drut, Pyle and Crawford, 1994; Peterson, 1970). Forb cover increased 2.5 fold from 2004 to 2005 due to increased precipitation across my study area. As forb cover increased, broods may have been able to forage in a variety of cover types in 2005. The added herbaceous cover may have added a component making chicks less visible in a variety of cover types. Coggins' (1998) brood use was equitably distributed between cover types in wet years more than dry years because of the greater availability of forbs. 
Increased food availability and cover have the potential to increase survival of chicks (Crawford et al., 2004). On our study area there was 71 percent brood survival in 2004, and 84 percent in 2005 (brood survival is the survival of at least one chick to 30 days of age) (Sika, 2006). Increased grass height, total herbaceous cover and forb cover, likely increased chick survival.

Table 1. Maximum, minimum, and average temperature, total precipitation, and total snow depth from January to December in 2004 to 2006 at station 247220 in Roundup, MT (National Oceanic and Atmospheric Administration, 2006).

\begin{tabular}{|c|c|c|c|c|c|c|}
\hline Year & Month & $\begin{array}{c}\text { Average maximum } \\
\text { Temp. }{ }^{\circ} \mathrm{F}\end{array}$ & $\begin{array}{c}\text { Average minimum } \\
\text { Temp. }{ }^{\circ} \mathrm{F}\end{array}$ & $\begin{array}{c}\text { Average } \\
\text { Temp. }{ }^{\circ} \mathrm{F}\end{array}$ & $\begin{array}{c}\text { Total } \\
\text { Precip.(in) }\end{array}$ & $\begin{array}{c}\text { Total Snow } \\
\text { (in) }\end{array}$ \\
\hline 2004 & Jan & 33 & 12 & 22.5 & 0.4 & 7.5 \\
\hline 2004 & Feb & 43 & 19 & 31 & 0.26 & 0.5 \\
\hline 2004 & March & 60 & 30 & 45 & 0.11 & 0.5 \\
\hline 2004 & December & 46 & 21 & 33.5 & 0.39 & 4.2 \\
\hline 2005 & Jan & 33 & 11 & 22 & 0.26 & 6.5 \\
\hline 2005 & Feb & 49 & 19 & 34 & Trace & Trace \\
\hline 2005 & March & 54 & 27 & 27 & 0.63 & 6.4 \\
\hline 2005 & December & 36 & 18 & 37.5 & 0.33 & 4.5 \\
\hline 2006 & Jan & 47 & 28 & 29 & 0.22 & 0 \\
\hline 2006 & Feb & 42 & 16 & 34.5 & 1.55 & 1.4 \\
\hline 2006 & March & 47 & 22 & & & 8 \\
\hline
\end{tabular}

Due to unfavorable precipitation and a lack of forbs, the food source for chicks could have been comprised more from sagebrush than forbs in 2004. This could be why sagebrush density was higher in 2004 than 2005. Drut, Crawford and Gregg (1994) found chick diets in Oregon to correspond directly to the availability of primary foods. Forbs and invertebrates constituted $>75$ percent of the diet at Hart Mountain, while sagebrush composed 65 percent of the mass consumed by chicks at Jackass Creek. Peterson (1970) in central Montana and Klebenow and Gray (1968) in Idaho found young sage-grouse ate mostly forbs and insects and very little sagebrush until they were $\geq 10$ weeks old.

\subsection{Winter Habitat}

Both winters were relatively mild with no snow accumulations $>10 \mathrm{~cm}$ on days we collected bird locations and no more than $20 \mathrm{~cm}$ of snow fell within a month (table 1). Shrub height was greater at winter non-use sites than use sites in 2005 (36 cm vs. $32 \mathrm{~cm} ; P<0.01$ ), but similar in $2004(27 \mathrm{~cm}$ vs. $27 \mathrm{~cm}$ ). Most winter studies have found height of sagebrush to be an important determinant of sage-grouse habitat because sagebrush availability above the snow pack has been determined to be critical for sage-grouse survival (Wallestad, 1975; Beck, 1977; Robertson, 1991). Snow never completely covered sagebrush during the 2 years of this study. In a study in the Yellow-Water Triangle of Montana, <15 kilometers north of our Musselshell study site, Wallestad (1975) found sage-grouse restricted to 7 percent of their available range when snow depths exceeded $30 \mathrm{~cm}$. This occurred in 3 of the 7 winters of his 
study. It is not known where sage-grouse will go under harsh winter conditions on our study area.

Despite our sampling occurring during mild winters, shrub cover (12 percent vs. 10 percent) and density $\left(1.2 / \mathrm{m}^{2}\right.$ vs. $\left.0.8 / \mathrm{m}^{2}\right)$ were greater $(P<0.001)$ at winter use sites than non-use sites. This is similar to findings in Idaho sage-grouse winter habitats (Robertson, 1991). During the winter sage-grouse were almost completely reliant on sagebrush as a food and cover source (Patterson, 1952; Wallestad, 1975). Sage-grouse were able to maintain or gain weight during the winter (Patterson, 1952; Remington and Braun, 1988) because of their nutritious diet (Wambolt, 2004) of abundant sagebrush.

Shrub density and cover were greater $(P<0.001)$ in 2004 than 2005 . Winter weather conditions were similar for both years. In the fall of 2005, 800 ac of important winter habitat in Musselshell County were plowed, making it unavailable for use during the 2005 to 2006 winter. While it appeared that birds had plenty of similar habitats available they were still found in the plowed area and in adjacent habitat that appeared less than ideal. The 10 sites immediately surrounding the newly plowed area during the 2005 winter had a shrub canopy cover of 7.2 percent and a density of $0.86 \mathrm{shrubs} / \mathrm{m}^{2}$. Sage-grouse in our study area returned to wintering grounds and Berry and Eng (1985) reported similar findings. Swenson, Simmons and Eustace (1987) in south-central Montana found that sage-grouse populations declined by 73 percent after 30 percent of a known sage-grouse winter habitat was plowed. On our study area, lek numbers increased the year following the plowing (MTFWP unpublished data), possibly due to the wet productive spring before. Declines in population numbers could occur in the future if the study area received harsh winter conditions.

Sika (2006) found monthly winter survival to be lower in the 2005 winter than the 2004 winter on our study area. Because reproductive effort was higher in 2005, Sika (2006) attributed the decline in survival to trade-offs between survival and reproductive effort. The differences in habitat between the 2 years (decreased density and cover in 2005) could have been related to decreased survival in 2005. It is possible that sage-grouse chose habitats that were less suitable causing mortality. It is also possible that sage-grouse chose habitats to mitigate high mortality, for example they may have used habitats with less density and cover in order to be able to visualize and avoid predators.

Residual grass height (19 cm vs. $18 \mathrm{~cm})$ and cover (13 percent vs. 14 percent) were similar at winter use and non-use sites. Because grass heights measured for residual grass height in the winter of 2005 to 2006 included inflorescences the heights are not comparable with nest and brood residual grass heights were vegetative droop heights were measured. Sage-grouse did not appear to be selecting areas with vegetative cover in the winter. To our knowledge, no other study has addressed the importance of herbaceous cover in the winter. Selection for areas with greater herbaceous cover seems to be restricted to nesting and brood rearing activities when predator avoidance requires hiding.

Our winter use sites had less shrub cover $(P<0.001)$ than nest sites $(12$ percent vs. 15 percent), seemingly in conflict with Wallestad (1975) who found nest and winter habitats to be synonymous in central Montana. We believe our winter sites were low in cover, height, and 
density compared to other studies because snow depth was not great enough during this study to influence sage-grouse distribution. Wallestad's (1975) study included 3 of 7 winters which were above average in snow accumulation. If our study had occurred in similar winters it is likely that the winter habitat could have been similar to nesting habitat.

Other studies have found brood sites to have less shrub cover than random sites and nest sites to have greater shrub cover than random sites (Hagen, Connelly, and Schroeder, 2007); however we found the 2 habitats (nest and brood) to be similar in our study area. We removed all non-shrub habitats from our analysis in order to compare shrub habitats; if this had not been done the average cover of shrubs at brood sites would have been lower. As forbs desiccate, sage-grouse often moved to more mesic sites in other studies (Connelly, Schroeder, Sands and Braun, 2000). Birds in our study were non-migratory with movements typically less than $10 \mathrm{~km}$ between seasonal habitats, therefore, nesting and brood rearing routinely took place within close proximity.

Logically, because of difference in season, brood sites had greater grass height than nest sites and nest sites had greater residual grass height than brood sites $(P<0.02)$. Total herbaceous cover and forb cover were greater $(P<0.04)$ at brood sites, but grass cover was similar at nest and brood sites. Residual grass height was lower at brood sites because live grass was providing greater cover than residual grass and because residual grass was continually degrading as the season progressed.

Wallestad (1975) analyzed sage-grouse production over 10 years and found that rain during the laying season resulted in poor production due to a late hatch, but spring rainfall increased production overall. The spring of 2005 was rainy during the laying period in early May and until the end of June. More nests failed in 2005 than 2004, but the hens were able to re-nest, and re-nests were more successful (Sika 2006). The continuing rain may have enabled the green up period to last long enough to promote chick survival. Due to increased precipitation, total herbaceous, grass and forb cover were greater in 2005 than $2004(P<0.05)$. The proportion of hens that successfully raised a brood to 30 days of age increased from 28 percent in 2004 to 43 percent in 2005 (Sika 2006). Lek counts increased between 30 to 50 percent from 2005 to 2006 (MTFWP unpublished data) verifying high recruitment from the 2005 breeding season. Moynahan (2004) also observed greater re-nesting in a year when $1^{\text {st }}$ nest survival was low to moderate and habitat conditions were favorable.

\section{Conclusion}

Sage-grouse habitats should be managed to include sagebrush, forbs, and grass. Herbaceous vegetation was more important during nesting and brood rearing than during the winter. Therefore, some portions of sage-grouse habitat may benefit from management for greater herbaceous cover, but sagebrush should not be removed. Sagebrush cover from 10 to 15 percent was the most consistent component of sage-grouse habitat.

\section{Acknowledgement}

We would like to acknowledge the financial support of the US Fish and Wildlife Service, Montana Fish, Wildlife \& Parks, the August L. Hormay Scholarship Fund, and the Bureau of 
Land Management. Field assistance was provided by David Keto, Amy Anderson, Linnette Sutphin and Mark Goetz.

\section{References}

Beck, T. D. I. (1977). Sage grouse flock characteristics and habitat selection in winter. Journal of Wildlife Management, 41(1), 18-26. http://dx.doi.org/10.2307/3800086

Berry, J. D., \& R. L. Eng. (1985). Interseasonal movements and fidelity to seasonal use areas by female sage grouse. Journal of Wildlife Management, 49(1), 237-240. http://dx.doi.org/10.2307/3801877

Boyd, C. S., Beck, J. L., \& Tanaka, J. A. (2014). Livestock grazing and Sage-Grouse habitat: impacts and opportunities. Journal of Rangeland Applications, 1, 58-77.

Braun, C. E. (1998). Sagegrouse declines in western North America: What are the problems? Proclamation of the Western Association of State Fish and Wildlife Agencies, 78, 139-156.

Canfield, R. H. (1941). Application of the line interception method in sampling range vegetation. Journal of Forestry, 39, 388-394.

Connelly, J. W., M. A. Schroeder, A. R. Sands, \& C. E. Braun. (2000). Guidelines to manage sage grouse populations and their habitats. Wildlife Society Bulletin, 28(4), 967-985.

Connelly, J. W., K. P. Reese, \& M. A. Schroeder. (2003). Monitoring of greater sage-grouse habitats and populations. University of Idaho, College of Natural Resources Experiment Station Bulletin, 80. Moscow, ID.

Connelly, J. W., Rinkes, E. T., \& Braun, C. E. (2011). Characteristics of greater sage-grouse habitats: a landscape species at micro and macro scales. Studies in Avian Biology, 38, 69-83.

Coggins, K. A. (1998). Relationship between habitat changes and productivity of sage grouse at Hart Mountain National Antelope Refuge, Oregon (Doctoral dissertation).

Crawford, J. A., Olson, R. A., West, N. E., Mosley, J. C., Schroeder, M. A., Whitson, T. D., \& Boyd, C. S. (2004). Ecology and management of sage-grouse and sage-grouse habitat. $\begin{array}{llll}\text { Rangeland Ecology } \quad \& \quad \text { Management, } & 57(1), & 2-19 .\end{array}$ http://dx.doi.org/10.2111/1551-5028(2004)057[0002:EAMOSA]2.0.CO;2

Daubenmire, R. F. (1959). A canopy coverage method of vegetation analysis. Northwest Science, 33, 43-64.

DeLong, A. K., Crawford, J. A., \& DeLong Jr, D. C. (1995). Relationships between vegetational structure and predation of artificial sage grouse nests. The Journal of wildlife management, 88-92. http://dx.doi.org/10.2307/3809119

Dinkins, J. B., Conover, M. R., Kirol, C. P., \& Beck, J. L. (2012). Greater Sage-Grouse (Centrocercus urophasianus) select nest sites and brood sites away from avian predators. The Auk, 129(4), 600-610. http://dx.doi.org/10.1525/auk.2012.12009

Dinkins, J. B., Conover, M. R., Kirol, C. P., Beck, J. L., \& Frey, S. N. (2014). Greater 
Sage-Grouse (Centrocercus urophasianus) select habitat based on avian predators, landscape composition, and anthropogenic features. The Condor, 116(4), 629-642. http://dx.doi.org/10.1650/CONDOR-13-163.1

Doherty, K. E., Naugle, D. E., Walker, B. L., \& Graham, J. M. (2008). Greater sage-grouse winter habitat selection and energy development. Journal of Wildlife Management, 72(1), 187-195. http://dx.doi.org/10.2193/2006-454

Drut, M. S., Crawford, J. A., \& Gregg, M. A. (1994). Brood habitat use by sage grouse in Oregon. The Great Basin Naturalist, 170-176.

Drut, M. S., Pyle, W. H., \& Crawford, J. A. (1994). Diets and food selection of sage grouse chicks in Oregon. Journal of Range Management, 90-93. http://dx.doi.org/10.2307/4002848

Dzialak, M. R., Webb, S. L., Harju, S. M., Olson, C. V., Winstead, J. B., \& Hayden-Wing, L. D. (2013). Greater sage-grouse and severe winter conditions: identifying habitat for conservation. Rangeland Ecology \& Management, 66(1), 10-18. http://dx.doi.org/10.2111/REM-D-11-00223.1

Eng, R. L., \& Schladweiler, P. (1972). Sage grouse winter movements and habitat use in central Montana. The Journal of Wildlife Management, 141-146. http://dx.doi.org/10.2307/3799198

Hagen, C. A., Connelly, J. W., \& Schroeder, M. A. (2007). A meta-analysis of greater sage-grouse Centrocercus urophasianus nesting and brood-rearing habitats. Wildlife Biology, 13(sp1), 42-50. http://dx.doi.org/10.2981/0909-6396(2007)13[42:AMOGSC]2.0.CO;2

Hausleitner, D. (2003). Population dynamics, habitat use and movements of greater sage-grouse in Moffat County, Colorado (Master's thesis)

Holloran, M. J. (1999). Sage grouse (Centrocercus urophasianus) seasonal habitat use near Casper, Wyoming. [Thesis]

Holloran, M. J., \& Anderson, S. H. (2005). Spatial distribution of greater sage-grouse nests in relatively contiguous sagebrush habitats. The Condor, 107(4), 742-752. http://dx.doi.org/10.1650/7749.1

Holloran, M. J., Heath, B. J., Lyon, A. G., Slater, S. J., Kuipers, J. L., \& Anderson, S. H. (2005). Greater sage-grouse nesting habitat selection and success in Wyoming. Journal of Wildlife Management, 69(2), 638-649. http://dx.doi.org/10.2193/0022-541X(2005)069[0638:GSNHSA]2.0.CO;2

Kirol, C. P., Beck, J. L., Dinkins, J. B., \& Conover, M. R. (2012). Microhabitat selection for nesting and brood-rearing by the greater sage-grouse in xeric big sagebrush. The Condor, 114(1), 75-89. http://dx.doi.org/10.1525/cond.2012.110024

Klebenow, D. A., \& Gray, G. M. (1968). Food habits of juvenile sage grouse. Journal of Range Management, 80-83. http://dx.doi.org/10.2307/3896359

Klebenow, D. A. (1969). Sage grouse nesting and brood habitat in Idaho. The Journal of 
Wildlife Management, 649-662. http://dx.doi.org/10.2307/3799390

Kramer, C. Y. (1956). Extension of multiple range tests to group means with unequal numbers of replications. Biometrics, 12(3), 307-310. http://dx.doi.org/10.2307/3001469

Mabray, S. T., \& Conover, M. R. (2015). Microhabitat selection by greater sage-grouse hens during brood rearing. Human-Wildlife Interactions, 9(2), 219.

Montana Sage-grouse Work Group. (2002). Management plan and conservation strategies for sage-grouse in Montana-final draft plan. Montana Sage-grouse Work Group. 200p.

Moynahan, B. J. (2004). Landscape-scale factors affecting population dynamics of greater sage grouse (Centerocercus urophasianus) in north-central Montana. (Doctoral dissertation)

National Oceanic Atmospheric Administration. (2006). Annual climatological summary, Roundup, Montana. Available at: http://cdo.ncdc.noaa.gov/ancsum/ACS. Accessed August 3rd, 2006.

Patterson, R. L. (1952). The sage grouse in Wyoming, Denver: Sage Books, Inc.

Peterson, J. G. (1970). The food habits and summer distribution of juvenile sage grouse in central Montana. The Journal of Wildlife Management, 147-155. http://dx.doi.org/10.2307/3799502

Remington, T. E., \& Braun, C. E. (1985). Sage grouse food selection in winter, North Park, Colorado. The Journal of wildlife management, 1055-1061. http://dx.doi.org/10.2307/3801395

Remington, T. E., \& Braun, C. E. (1988). Carcass composition and energy reserves of sage grouse during winter. The Condor, 15-19. http://dx.doi.org/10.2307/1368427

Robertson, M. D. (1991). Winter ecology of migratory Sage Grouse and associated effects of prescribed fire in southeastern Idaho. M.S. thesis, University of Idaho. Moscow, ID.

Sika, J. L. (2006). Breeding ecology, survival rates, and causes of mortality of hunted and nonhunted greater sage-grouse in central Montana (Doctoral dissertation, Montana State University-Bozeman, College of Letters \& Science).

Schroeder, M. A., J. W. Connelly, C. L. Wambolt, C. E. Braun, C. A. Hagen, \& M. R. Frisina. (2006). Society for range management issue paper: ecology and management of sage-grouse $\begin{array}{lllll}\text { and } & \text { sage-grouse } & \text { habitat. } & \text { Rangelands. }\end{array}$ http://dx.doi.org/10.2111/1551-501X(2006)28[3:SFRMIP]2.0.CO;2

Sveum, C. M., Edge, W. D., \& Crawford, J. A. (1998). Nesting habitat selection by sage grouse in south-central Washington. Journal of Range Management, 265-269. http://dx.doi.org/10.2307/4003409

Swenson, J. E., Simmons, C. A., \& Eustace, C. D. (1987). Decrease of sage grouse Centrocerus urophasianus after ploughing of sagebrush steppe. Biological Conservation, 41(2), 125-132. http://dx.doi.org/10.1016/0006-3207(87)90115-7 


\section{Macrothink}

Thacker, E. T., Gardner, D. R., Messmer, T. A., Guttery, M. R., \& Dahlgren, D. K. (2012). Using gas chromatography to determine winter diets of greater sage-grouse in Utah. The Journal of Wildlife Management, 76(3), 588-592. http://dx.doi.org/10.1002/jwmg.273

USDA. (2003). Soil survey of Musselshell County, Montana. Natural Resource Conservation Service, Bozeman, MT.

Wallestad, R. O. (1975). Life history and habitat requirements of sage-grouse in central Montana. Montana Fish and Game Department, Technical Bulletin, Helena, MT.

Wambolt, C. L. (2004). Browsing and plant age relationships to winter protein and fiber of big sagebrush subspecies. Rangeland Ecology \& Management, 57(6), 620-623. http://dx.doi.org/10.2111/1551-5028(2004)057[0620:BAPART]2.0.CO;2

Wambolt, C. L., Creamer, W. H., \& Rossi, R. J. (1994). Predicting big sagebrush winter forage by subspecies and browse form class. Journal of Range Management, 231-234. http://dx.doi.org/10.2307/4003022

Western Regional Climate Center. (2005). Roundup, Montana Climate Summary. Available at: http://www.wrcc.dri.edu/summary/climsmmt.html. Accessed March 3, 2005.

\section{Copyright Disclaimer}

Copyright for this article is retained by the author(s), with first publication rights granted to the journal.

This is an open-access article distributed under the terms and conditions of the Creative Commons Attribution license (http://creativecommons.org/licenses/by/3.0/). 